\title{
Penerapan Data Mining Untuk Koperasi Se-Jawa Barat Menggunakan Metode Clustering pada Kementerian Koperasi dan UKM
}

\author{
L Magdalena ${ }^{1}$, R Fahrudin ${ }^{2}$ \\ Sekolah Tinggi Manajemen Informatika dan Komputer CIC Cirebon \\ J1. Kesambi 202, Kota Cirebon, Jawa Barat. Telp: (0231) 220250. \\ e-mail: lena.magdalena@cic.ac.id ${ }^{1}$,rifqifhrdn@mail.com²
}

\begin{abstract}
Abstrak
Penelitian ini bertujuan untuk menegelompokan data koperasi di Jawa Barat. Metode kalster yang digunakan dalam penelitian ini adalah K-Means, dalam klaster K-Means memiliki tingkat akurasi yang baik. Penelitian ini mengkaji bagaimana penggunaan metode K-means dalam studi kasus koperasi di Jawa Barat. Dari hasil pengelompokan menggunakan metode K-Means berdasarkan nilai Modal Sendiri, Modal Luar dan Volume Usaha, maka dihasilkan 3 klaster dengan nilai klaster tinggi, sedang dan rendah. Berdasarkan hasil tersebut menunjukan bahwa metode K-Means dapat digunakan untuk pengendalian atau pemantauan koperasi yang harus dipertahankan usahanya dan koperasi yang harus lebih ditingkatkan usahanya untuk membantu perekonomian nasional. Hasil dari klaster metode K-Means dapat dijadikan masukan bagi Kementrian Koperasi dan UKM sebagai bentuk pemetaan terhadap koperasi di Jawa Barat
\end{abstract}

Kata kunci: Koperasi, Klaster, K-Means

\section{Abstract}

This study purpose to group koperasi data in West Java. The kalster method used in this study is $K$-Means, in the K-Means cluster it has a good degree of accuracy. This study examines how to use the $K$ means method in a cooperative case study in West Java. From the results of the grouping using the $K$ Means method based on the value of Own Capital, External Capital and Business Volume, then produced 3 clusters with high, medium and low cluster values. Based on these results it shows that the K-Means method can be used for the control or monitoring of cooperatives that must be maintained in their businesses and cooperatives which must be further improved in order to help the national economy. The results of the K-Means method can be used as input for the Ministry of Koperasi and SDM as a form of mapping of koperasi in West Java

Keywords: Koperasi, Cluster, K-Means

\section{PENDAHULUAN}

\subsection{Latar Belakang}

Koperasi pada intinya adalah pembentukan badan usaha yang bertujuan untuk menggalang modal dan kerja sama untuk mencapai tujuan anggota. Pembentukan badan usaha koperasi bertujuan untuk memenuhi kebutuhan barang dan jasa bagi para anggota, baik yang bersifat individual maupun kelompok. Perekonomian nasional dengan demikian menjadi sangatlah penting dalam usaha mencapai cita-cita yang diharapkan. Perekonomian yang tujuan utamanya adalah pemerataan dan pertumbuhan ekonomi bagi seluruh rakyat Indonesia. Sebab, tanpa perekonomian nasional yang kuat dan memihak kepada rakyat maka tidak akan terwujud cita- cita tersebut.

Koperasi memperoleh hak untuk hidup dan berkembang di Indonesia. Koperasi yang sudah dibangun selama ini juga jumlahnya sudah cukup banyak. Jumlah ini merupakan aset yang harus dipelihara dan diberdayakan agar dapat berkembang membantu pemerintah untuk memerangi kemiskinan dan menyediakan lapangan kerja. Jika sekarang masih banyak koperasi yang tumbuh belum mampu mencapai tujuan bersama anggotanya, mereka harus diberdayakan melalui pendidikan. Pendidikan adalah 
usaha sadar untuk meningkatkan kemampuan memahami jati diri dan menerapkannya di dalam dunia nyata.

Penelitian ini menggunakan data mining [1] dengan analisa klaster [2]. Analisis klaster merupakan suatu teknik multivariat dengan tujuan utama mengelompokkan objek-objek berdasarkan karakteristik yang dimiliki. Dalam pengelompokannya digunakan suatu ukuran yang dapat menerangkan kedekatan antar data untuk menerangkan struktur grup sederhana dari data yang kompleks, yaitu ukuran jarak. Ukuran jarak [3] yang sering digunakan adalah ukuran jarak Euclidean [4]. Dalam hal ini peneliti mengangkat topik koperasi di Jawa Barat berdasarkan Modal Sendiri, Modal Luard an Volume Usaha, dimana proses metode yang dilakukan adalah analisis klaster.

Penelitian ini mencoba melihat ketepatan hasil pengelompokan metode K-Means pada kasus pengelompokan koperasi di Jawab Barat. Metode K-Means dipilih karena dianggap sebagai metode yang dapat menghasilkan pengelompokan yang akurat terhadap data koperasi di Jawa Barat.

Hasil dari klaster metode K-Means [5] dapat dijadikan masukan bagi Kementrian Koperasi dan UKM sebagai bentuk pemetaan terhadap koperasi di Jawa Barat. Proses pemetaan dapat di klaster kedalam 3 (tiga) klaster yakni koperasi tinggi, koperasi sedang dan produk koperasi rendah.

\subsection{Rumusan Masalah}

Penelitian ini mencoba melihat ketepatan hasil pengelompokan metode K-Means pada kasus pengelompokan koperasi di Jawab Barat berdasakan Modal Sendiri, Modal Luar dan Volume Usaha. Metode K-Means dipilih karena dianggap sebagai metode yang dapat menghasilkan pengelompokan yang akurat pada data koperasi Jawa Barat.

\subsection{Tujuan Penelitian}

Penelitian ini bertujuan untuk menentukan titik centroid untuk mengelompokan data koperasi Jawa Barat berdasarkan Modal Sendiri, Modal Luar dan Volume Usaha. Tujuan selanjutnya adalah untuk menentukan klaster yang tepat untuk masing masing wilayah yang terdapat pada koperasi Jawa Barat.

\subsection{Batasan Masalah}

Data yang digunakan dalam penelitian ini hanya data histori tahun 2016 - 2018 berdasarkan Modal Sendiri, Modal Luar dan Volume Usaha dalam satuan rupiah. Penelitian ini hanya membahas pembagian klaster koperasi Jawa Baat berdasarkan Modal Sendiri, Modal Luar dan Volume Usaha.

\section{KAJIAN PUSTAKA}

Metode yang digunakan dalam penelitian ini adalah analisis klaster. Klaster adalah proses pengelompokan benda serupa ke dalam kelompok yang berbeda, atau lebih tepatnya partisi dari sebuah data set kedalam subset, sehingga data dalam setiap subset memiliki arti yang bermanfaat. Algoritma clustering terdiri dari dua bagian yaitu secara hirarkis dan secara partitional [6]. Algoritma hirarkis [7] menemukan cluster secara berurutan dimana klaster ditetapkan sebelumnya, sedangkan algoritma partitional [8] menentukan semua kelompok pada waktu tertentu. Teknik pengelompokan saat ini dapat diklasifikasikan menjadi tiga kategori yaitu partitional, hirarkis dan berbasis lokalitas algoritma. Terdapat satu set objek dan kriteria clustering atau pengelompokan, pengelompokan partitional mememperoleh partisi objek ke dalam cluster sehingga objek dalam klaster akan lebih mirip dengan benda-benda yang ada di dalam cluster dari pada objek yang terdapat pada klaster yang berbeda [9].

\subsection{Metode K-Means}

Algoritma K-means merupakan salah satu algoritma dengan partitional, karena K-Means didasarkan pada penentuan jumlah awal kelompok dengan mendefinisikan nilai centroid awalnya. Kmeans clustering merupakan salah satu metode data clustering non-hirarki yang mengelompokan data dalam bentuk satu atau lebih cluster/kelompok. Data-data yang memiliki karakteristik yang sama dikelompokan dalam satu cluster/ kelompok dan data yang memiliki karakteristik yang berbeda dikelompokan dengan cluster/kelompok yang lain sehingga data yang berada dalam satu cluster/kelompok memiliki tingkat variasi yang kecil

Langkah-langkah melakukan clustering dengan metode K-means adalah sebagai berikut : 1) Pilih jumlah cluster k; 2) Inisialisasi ke pusat cluster ini bisa dilakukan dengan berbagai cara. Cara yang 
paling sering dilakukan adalah dengan random atau acak. Pusat-pusat cluster diberiduberi nilai awal dengan angka-angka random; 3) Alokasikan semua data/objek ke cluster terdekat. Kedekatan dua objek ditentukan berdasarkan jarak kedua objek tersebut. Demikian juga kedekatan suatu data ke cluster tertentu ditentukan jarak antara data dengan pusat cluster [10]. Dalam tahap ini perlu dihitung jarak tiap data ke tiap pusat cluster. Jarak paling antara satu data dengan satu cluster tertentu akan menentukan suatu data masuk dalam cluster mana.

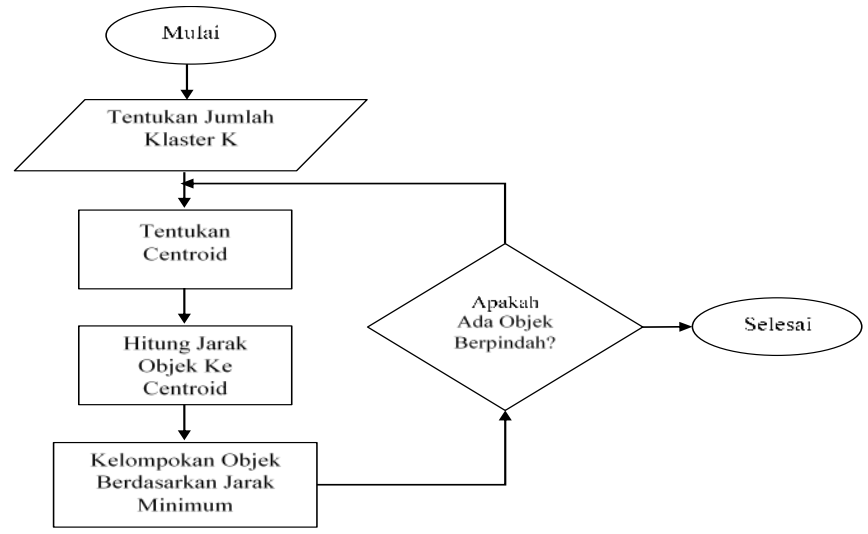

Gambar 1. K-Means Method

Proses pengelompokkan data ke dalam suatu cluster dapat dilakukan dengan cara menghitung jarak terdekat dari suatu data ke sebuah titik centroid. Untuk menghiutng jarak semua data ke setiap titik pusat cluster dapat menggunakan teori jarak Euclidean yang dirumuskan sebagai persamaan berikut [11]:

$$
D(i, j)=\sqrt{\left(x_{1 i}-X_{1 j}\right)^{2}}+\left(x_{2 i}-X_{2 j}\right)^{2}+\cdots+\left(x_{k i}-X_{k j}\right)^{2}
$$

Dimana :

$(i, j)=$ Jarak data keike pusat cluster $\mathrm{j}$

$x_{k i} \quad=$ Data ke i pada atribut data ke $\mathrm{k}$

$X_{k j} \quad=$ Titik pusat ke $\mathrm{j}$ pada atribut ke $\mathrm{k}$

Jarak pusat cluster dihitung kembali dengan keanggotaan cluster yang sekarang. Pusat cluster adalah rata-rata dari semua data/objek dalam cluster tertentu. Jika dikehendaki bisa juga menggunakan median dari cluster tersebut. Jadi rata-rata (mean) bukan satu-satunya ukuran yang bisa dipakai. Setiap objek kemudian ditugaskan kembali memakai pusat cluster yang baru.

\section{ANALISA DAN PERANCANGAN}

\subsection{Tahap Penelitian}

Tahap penelitian yang akan dilakukan adalah sebagai berikut : 1)Pengumpulan data histori koperasi Jawa Barat berdasarkan Modal Sendiri, Modal Luar dan Volume Usaha, 2) Seleksi data, melihat data yang digunakan dan tidak digunakan, 3) Mengolah data menggunakan algoritma K-Means Clustering 4) Hasil klaster menggunakan metode K-Means.

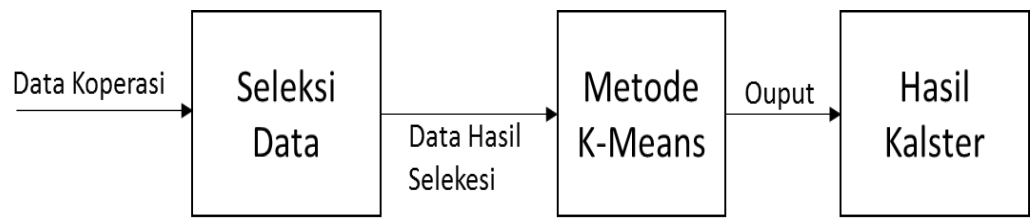

Gambar 2. Tahapan Penelitian 
Data koperasi Jawa Barat didpatkan dari Kementrian Koperasi Pusat, data berupa data koperasi Jawa Barat berdasarkan Modal Sendiri, Modal Luar dan Volume Usaha periode 2016 - 2018 dengan satuan rupiah. Dari data koperasi yang terkumpul pada setiap periodenya, kemudian dari hasil data tersebut dihasilkan data 27 koperasi kabupaten dan kota utama di Jawa Barat. Dengan demikian data tersebut telah dapat dikelompokan dengan menggunakan algoritma K-means Clustering. Hasil tersebut seperti yang ditunjukkan pada data di bawah ini:

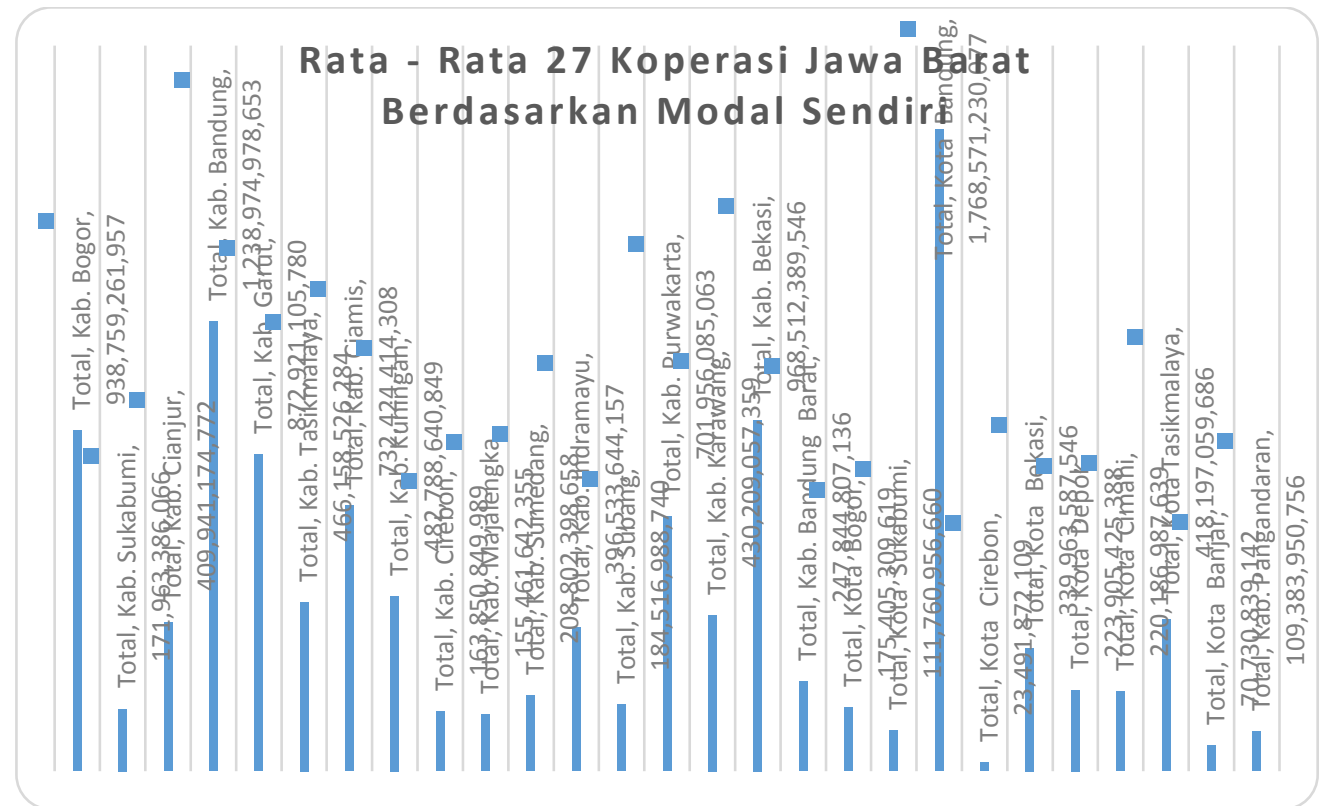

Gambar 3. Rata - Rata 27 Koperasi Jawa Barat Berdasarkan Modal Sendiri

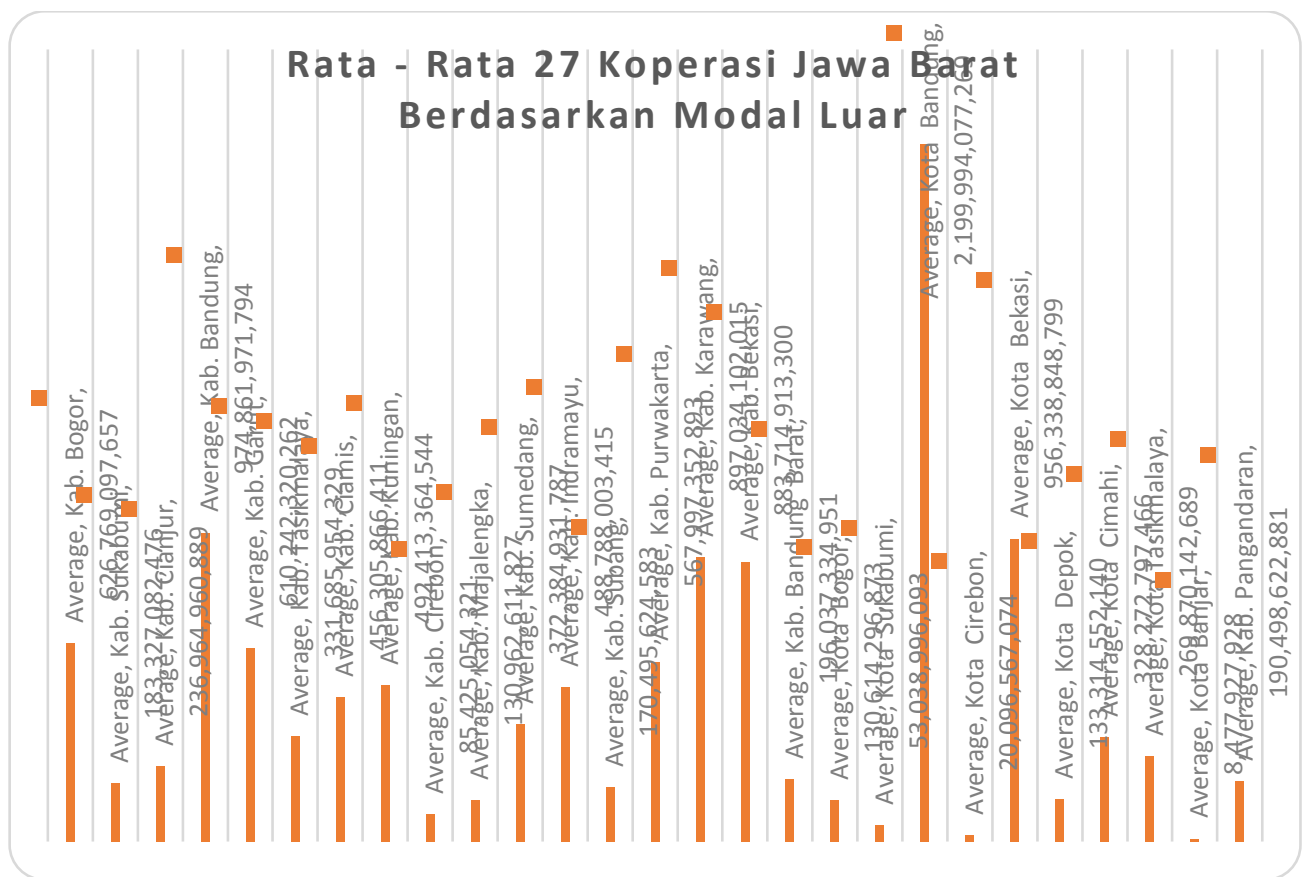

Gambar 4. Rata - Rata 27 Koperasi Jawa Barat Berdasarkan Modal Luar 


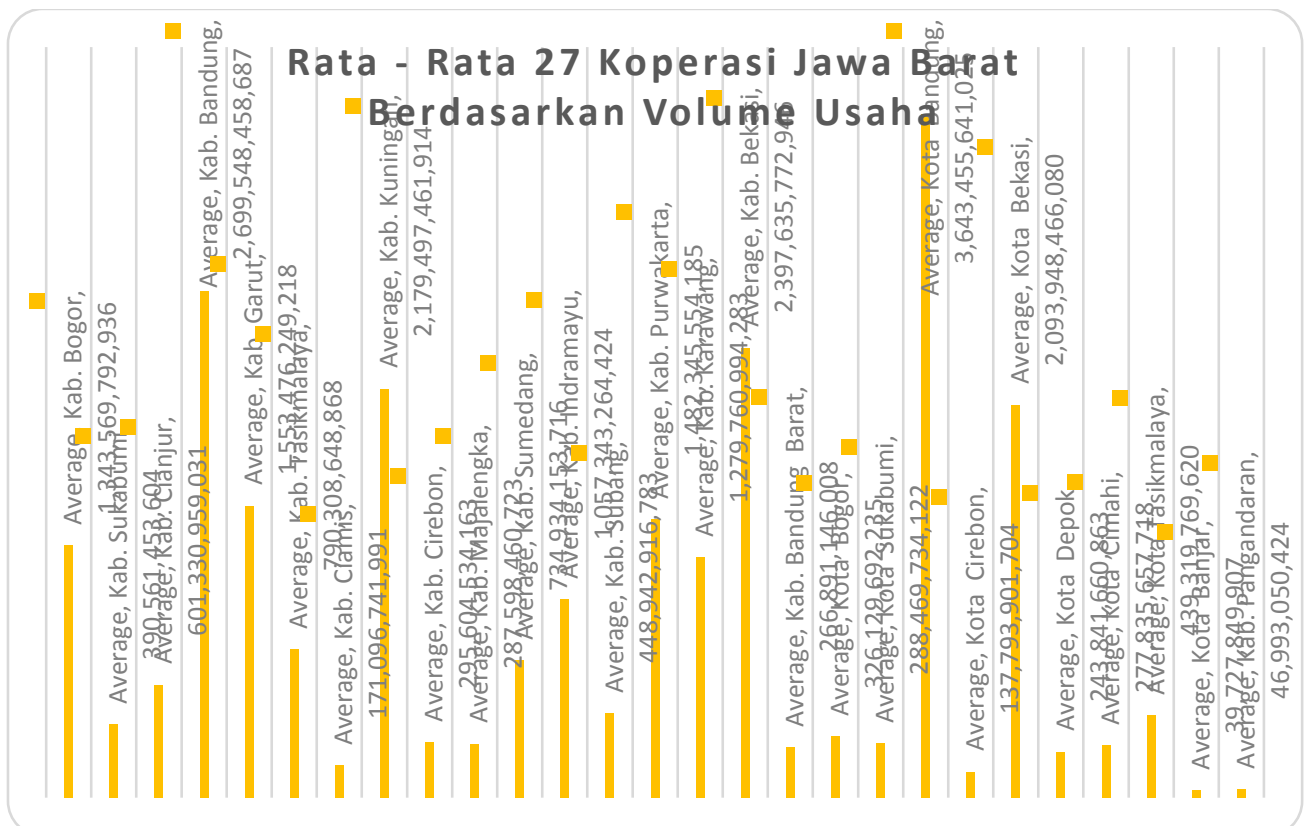

Gambar 5. Rata - Rata 27 Koperasi Jawa Barat Berdasarkan Volume Usaha

Gambar 3, 4 dan 5 adalah gambar data 27 koperasi di Jawa Barat dengan satuan rupiah. Data dalam bentuk data koperasi di Jawa Barat untuk periode 2016 - 2018, maka data dirata-rata berdasarkan Modal Sendiri, Modal Luar dan Volume Usaha.

\subsection{K-Means Berdasarkan Modal Sendiri}

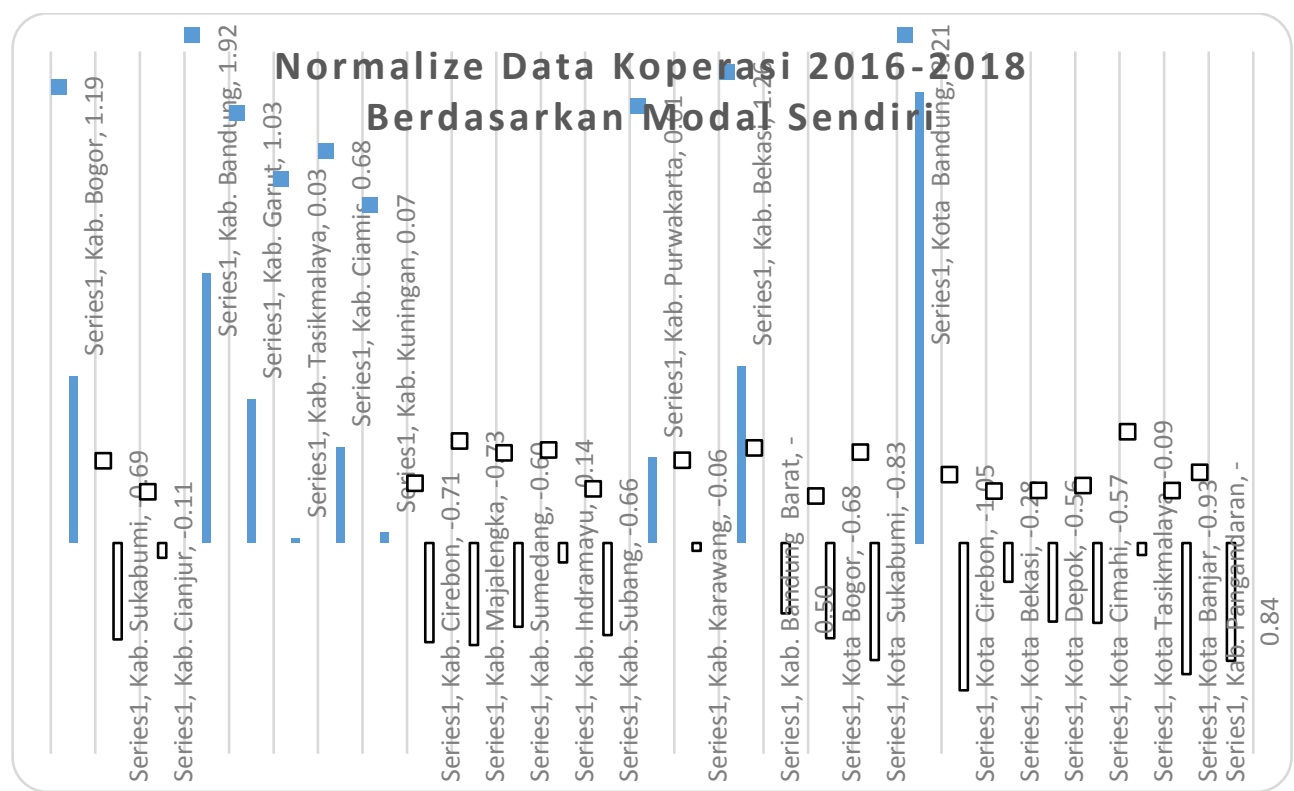

Gambar 3. Normalize Data Koperasi Berdasarkan Modal Sendiri

Gambar 6 adalah grafik normalisasi data 27 koperasi berdasarkan Modal Sendiri, setelah itu data sebenarnya dapat dikelompokkan menjadi 3 klaster. Dalam proses pengelompokan itu sendiri, 3 titik centroid ditetapkan secara acak. Hasil centroid ada pada tabel di bawah ini: 
Table 1 Table Centroid Berdasarkan Modal Sendiri

\begin{tabular}{|c|r|r|r|}
\hline Atribut & C1 & C2 & \multicolumn{1}{c|}{ C3 } \\
\hline Modal Sendiri & 2.56 & 0.95 & -0.49 \\
\hline
\end{tabular}

Tabel 1 menunjukkan hasil penerapan algoritma K-Means yang menghasilkan nilai titik tengah atau centroid dari data yang diperoleh klaster yang diinginkan adalah 3 klaster.

Tempatkan setiap data dalam klaster, dalam penelitian ini menggunakan metode k-means untuk mengalokasikan setiap data ke dalam sebuah klaster sehingga data akan dimasukkan dalam sebuah klaster yang memiliki jarak terdekat dengan titik pusat dari masing-masing klaster. Untuk mengetahui klaster mana yang paling dekat dengan data, perlu untuk menghitung jarak setiap data dengan titik pusat dari masing-masing klaster. Misalnya, jarak dari data pertama ke pusat klaster pertama akan dihitung, data rata-rata dan hasil normalisasi.

$$
D(1,1)=\sqrt{(1.19-2.56)^{2}}=-1.37
$$

Dari hasil perhitungan di atas, hasil menunjukkan bahwa jarak data pertama dengan pusat klaster pertama adalah -1.37

$$
D(1,2)=\sqrt{(1.19-0.95)^{2}}=0.24
$$

Dari hasil perhitungan di atas, hasil menunjukkan bahwa jarak data pertama dengan pusat klaster kedua adalah 0.24

$$
D(1,3)=\sqrt{(1.19-(-0.49))^{2}}=1.68
$$

Dari hasil perhitungan di atas, hasil menunjukkan bahwa jarak data pertama dengan pusat klaster ketiga adalah 1.68. Dari hasil perhitungan di atas, hasil menunjukkan bahwa jarak terdekat dari data pertama adalah pusat klaster kedua dengan nilai 0.24 .

Dalam menerapkan algoritma K-Means nilai titik tengah atau centroid dihasilkan dari data yang diperoleh klaster yang diinginkan adalah 3 klaster. Penentuan klaster dibagi menjadi tiga bagian: klaster koperasi berdasrkan Modal Sendiri tertinggi, klaster Modal Sendiri sedang, dan klaster Modal Sendiri terendah. Berikut ini adalah hasil pembagian klaster:

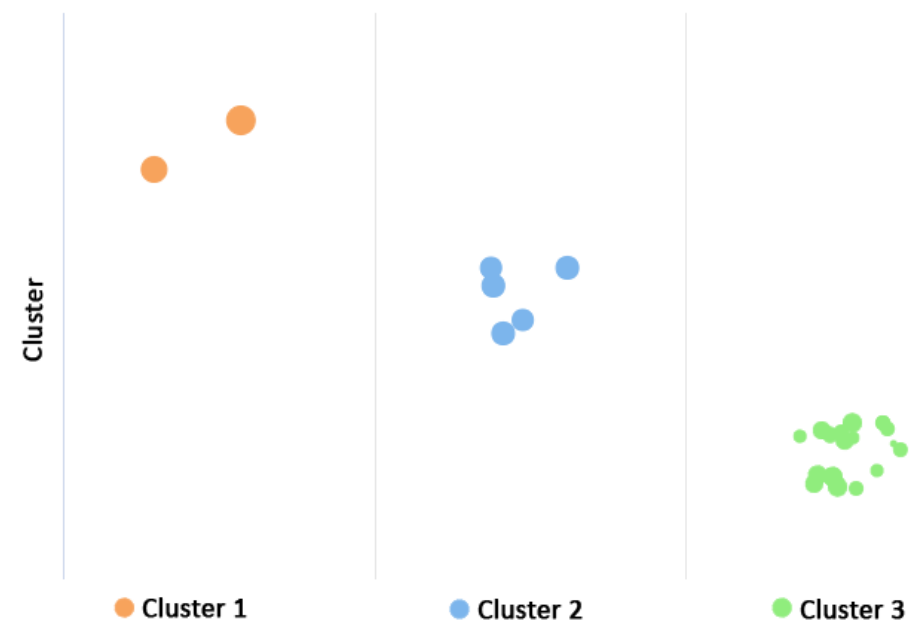

Gambar 4. Clustering Berdasarkan Modal Sendiri

Gambar 7 adalah hasil dari pengelompokan K-means berdasarkan Modal Sendiri degan satuan rupiah. Diketahui bahwa hasil pengelompokan data menunjukkan 27 data yang dikelompokkan menjadi 3 kelompok. Klaster pertama adalah 2 koperasi, klaster kedua adalah 5 koperasi dan klaster ketiga adalah 20 koperasi. 


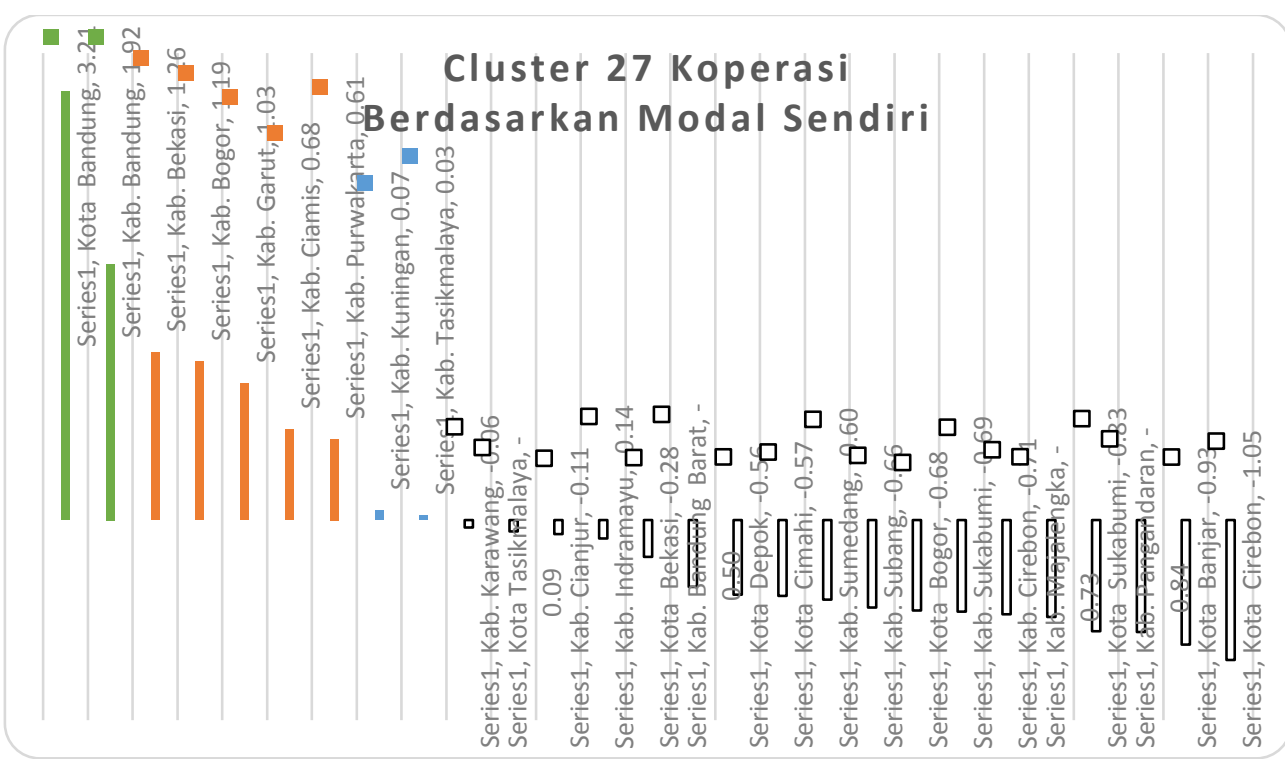

Gambar 5. Clustering Berdasarkan Modal Sendiri

Pada Gambar 8 di atas, kita bisa mengetahui nilai Modal Sendiri dari setiap koperasi di Jawa Barat. Pada klaster pertama 2 koperasi dengan nilai Modal Sendiri 1,238,974,978,653 1,768,571,230,077, klaster kedua dengan 5 koperasi dengan nilai Modal Sendiri 701,956,085,063 968,512,389,546 dan pada kluster ketiga memiliki 20 koperasi dengan Modal Sendiri 23,491,872,109 $482,788,640,849$.

\subsection{K-Means Berdasarkan Modal Luar}

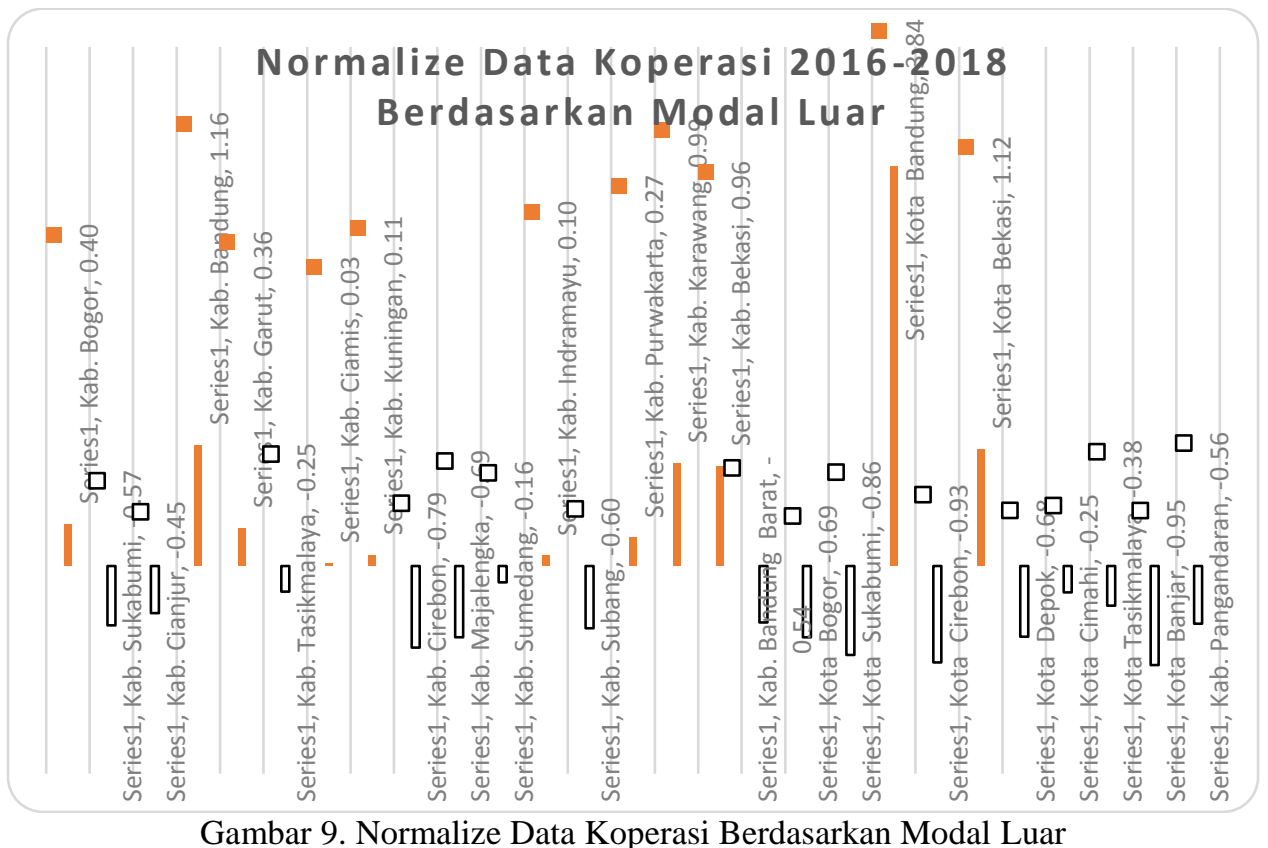

Gambar 9 adalah grafik normalisasi data 27 koperasi berdasarkan Modal Luar, setelah itu data sebenarnya dapat dikelompokkan menjadi 3 klaster. Dalam proses pengelompokan itu sendiri, 3 titik centroid ditetapkan secara acak. Hasil centroid ada pada tabel di bawah ini: 
Table 2. Table Centroid Berdasarkan Modal Luar

\begin{tabular}{|c|r|r|r|}
\hline Atribut & C1 & C2 & \multicolumn{1}{c|}{ C3 } \\
\hline Modal Luar & 3.84 & 0.60 & -0.54 \\
\hline
\end{tabular}

Tabel 2 menunjukkan hasil penerapan algoritma K-Means yang menghasilkan nilai titik tengah atau centroid dari data yang diperoleh klaster yang diinginkan adalah 3 klaster.

Tempatkan setiap data dalam klaster, dalam penelitian ini menggunakan metode k-means untuk mengalokasikan setiap data ke dalam sebuah klaster sehingga data akan dimasukkan dalam sebuah klaster yang memiliki jarak terdekat dengan titik pusat dari masing-masing klaster. Untuk mengetahui klaster mana yang paling dekat dengan data, perlu untuk menghitung jarak setiap data dengan titik pusat dari masing-masing klaster. Misalnya, jarak dari data pertama ke pusat klaster pertama akan dihitung, data rata-rata dan hasil normalisasi.

$$
D(1,1)=\sqrt{(1.19-3.84)^{2}}=-2.65
$$

Dari hasil perhitungan di atas, hasil menunjukkan bahwa jarak data pertama dengan pusat klaster pertama adalah -2.65

$$
D(1,2)=\sqrt{(1.19-0.60)^{2}}=0.59
$$

Dari hasil perhitungan di atas, hasil menunjukkan bahwa jarak data pertama dengan pusat klaster kedua adalah 0.59

$$
D(1,3)=\sqrt{(1.19-(-0.54))^{2}}=1.73
$$

Dari hasil perhitungan di atas, hasil menunjukkan bahwa jarak data pertama dengan pusat klaster ketiga adalah 1.73. Dari hasil perhitungan di atas, hasil menunjukkan bahwa jarak terdekat dari data pertama adalah pusat klaster kedua dengan nilai 0.60.

Dalam menerapkan algoritma K-Means nilai titik tengah atau centroid dihasilkan dari data yang diperoleh asalkan klaster yang diinginkan adalah 3 klaster. Penentuan klaster dibagi menjadi tiga bagian: klaster koperasi berdasrkan Modal Sendiri tertinggi, klaster Modal Sendiri sedang, dan klaster Modal Sendiri terendah. Berikut ini adalah hasil pembagian klaster:

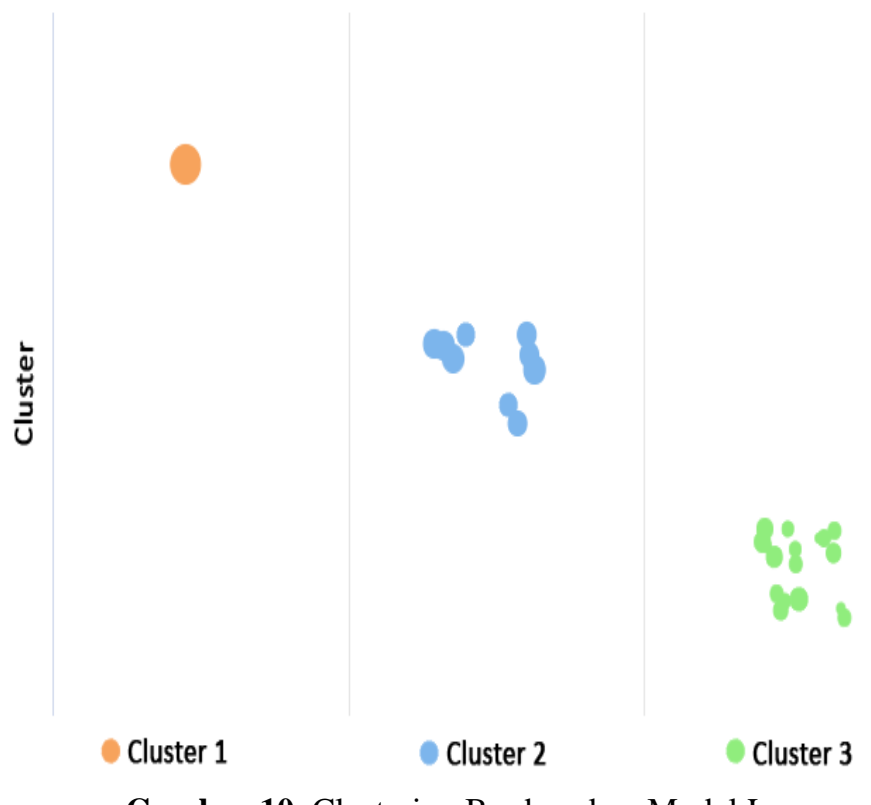

Gambar 10. Clustering Berdasarkan Modal Luar

Gambar 7 adalah hasil dari pengelompokan K-means berdasarkan nilai USD. Diketahui bahwa hasil pengelompokan data menunjukkan 27 data yang dikelompokkan menjadi 3 kelompok. Klaster pertama adalah 1 koperasi, klaster kedua adalah 9 koperasi dan klaster ketiga adalah 17 koperasi. 


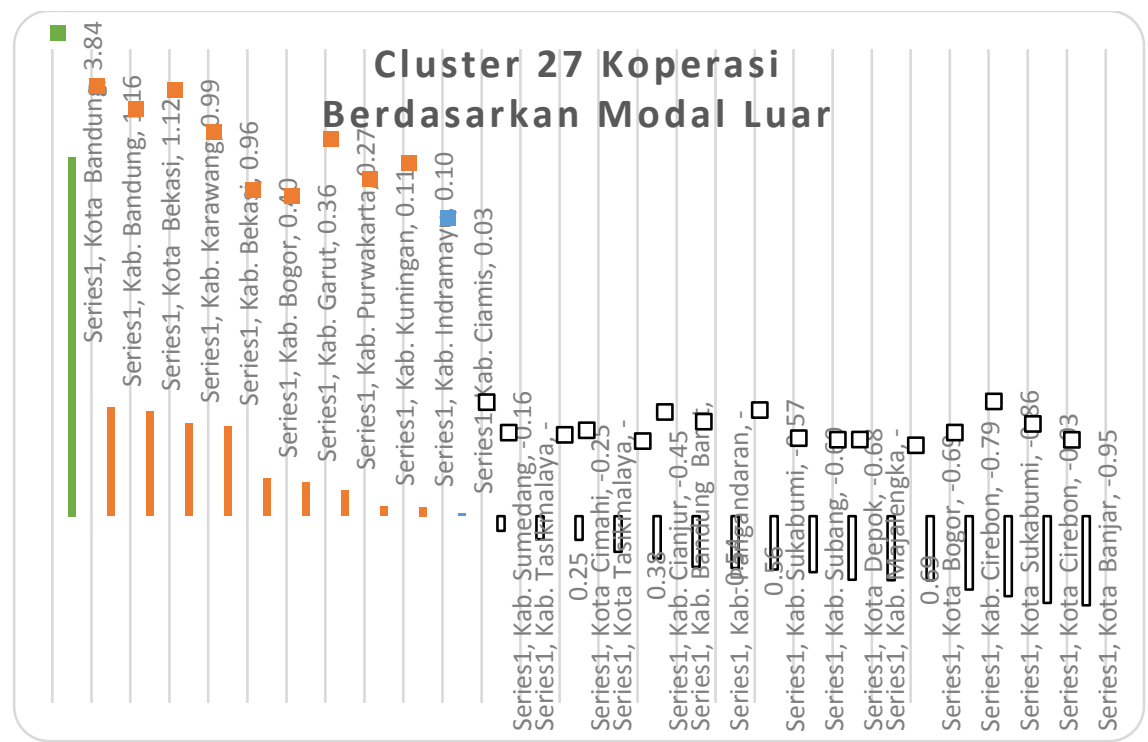

Gambar 11. Clustering Berdasarkan Modal Luar

Pada Gambar 11 di atas, kita bisa mengetahui nilai Modal Luar dari setiap koperasi di Jawa Barat. Pada klaster pertama 1 koperasi dengan nilai Modal Luar 2,199,994,077,269, klaster kedua dengan 9 koperasi dengan nilai Modal Luar 488,788,003,415 - 974,861,971,794 dan pada kluster ketiga memiliki 17 koperasi dengan Modal Luar 8,477,927,928 - 456,305,866,411.

\subsection{K-Means Berdasarkan Volume Usaha}

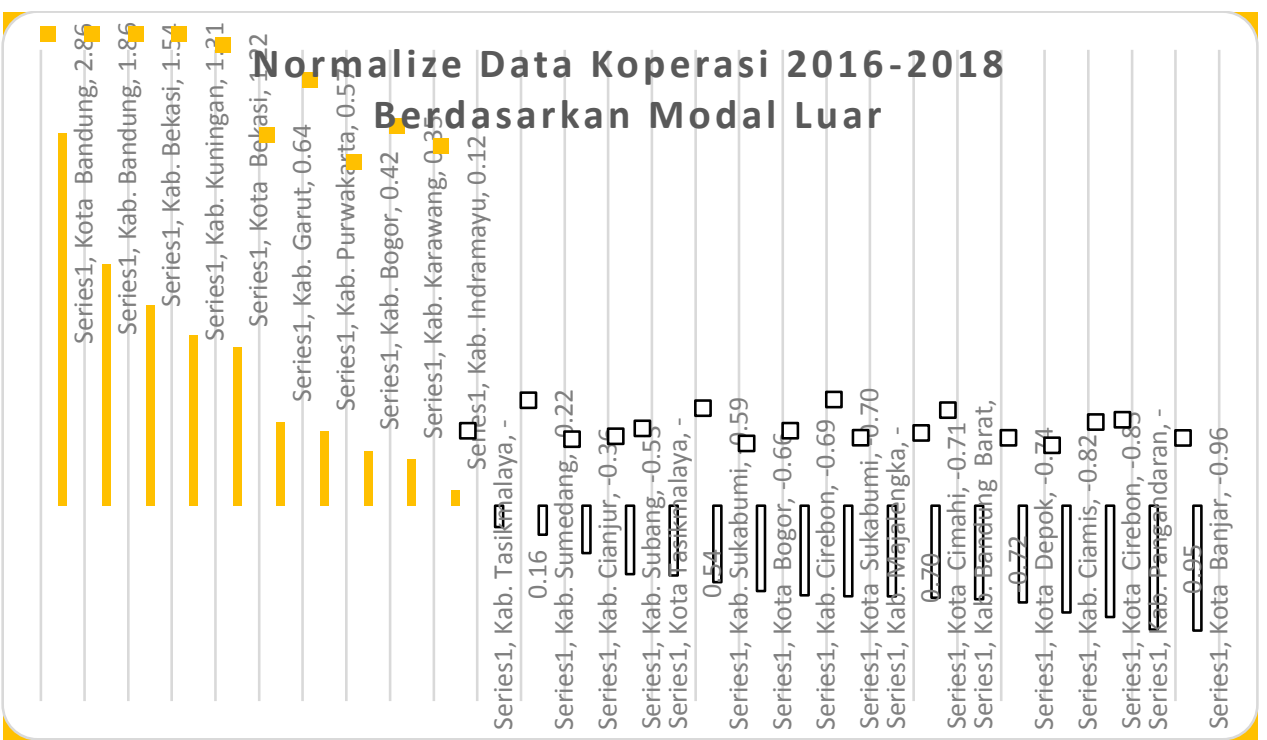

Gambar 12. Normalize Data Koperasi Berdasarkan Modal Sendiri

Gambar 12 adalah grafik normalisasi data 27 koperasi berdasarkan Volume Usaha, setelah itu data sebenarnya dapat dikelompokkan menjadi 3 klaster. Dalam proses pengelompokan itu sendiri, 3 titik centroid ditetapkan secara acak. Hasil centroid ada pada tabel di bawah ini:

Tabel 3. Table Centroid Berdasarkan Modal Sendiri

\begin{tabular}{|c|r|r|r|}
\hline Atribut & C1 & \multicolumn{1}{|c|}{ C2 } & \multicolumn{1}{|c|}{ C3 } \\
\hline Modal Sendiri & 2.35 & 0.77 & -0.64 \\
\hline
\end{tabular}


Tabel 3 menunjukkan hasil penerapan algoritma K-Means yang menghasilkan nilai titik tengah atau centroid dari data yang diperoleh asalkan cluster yang diinginkan adalah 3 cluster.

Tempatkan setiap data dalam klaster, dalam penelitian ini menggunakan metode k-means untuk mengalokasikan setiap data ke dalam sebuah cluster sehingga data akan dimasukkan dalam sebuah cluster yang memiliki jarak terdekat dengan titik pusat dari masing-masing cluster. Untuk mengetahui cluster mana yang paling dekat dengan data, perlu untuk menghitung jarak setiap data dengan titik pusat dari masing-masing cluster. Misalnya, jarak dari data pertama ke pusat cluster pertama akan dihitung, data rata-rata dan hasil normalisasi.

$$
D(1,1)=\sqrt{(1.19-2.35)^{2}}=-1.16
$$

Dari hasil perhitungan di atas, hasil menunjukkan bahwa jarak data pertama dengan pusat cluster pertama adalah -1.16

$$
D(1,2)=\sqrt{(1.19-0.77)^{2}}=0.42
$$

Dari hasil perhitungan di atas, hasil menunjukkan bahwa jarak data pertama dengan pusat cluster kedua adalah 0.42

$$
D(1,3)=\sqrt{(1.19-(-0.64))^{2}}=1.83
$$

Dari hasil perhitungan di atas, hasil menunjukkan bahwa jarak data pertama dengan pusat cluster ketiga adalah 1.83. Dari hasil perhitungan di atas, hasil menunjukkan bahwa jarak terdekat dari data pertama adalah pusat cluster kedua dengan nilai 0.77 .

Dalam menerapkan algoritma K-Means nilai titik tengah atau centroid dihasilkan dari data yang diperoleh asalkan cluster yang diinginkan adalah 3 cluster. Penentuan klaster dibagi menjadi tiga bagian: klaster koperasi berdasrkan Volume Usaha tertinggi, klaster Volume Usaha sedang, dan klaster Volume Usaha terendah. Berikut ini adalah hasil pembagian klaster:

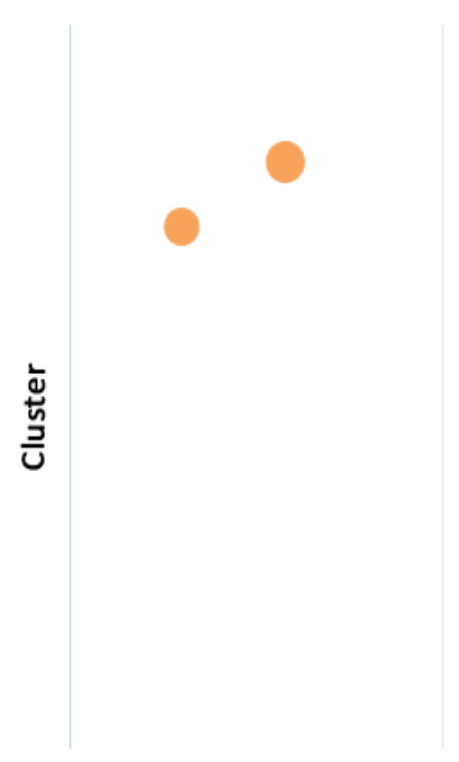

Cluster 1

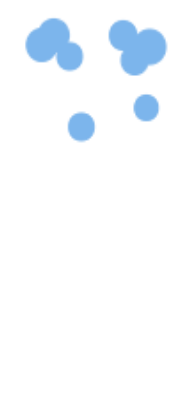

Cluster 2

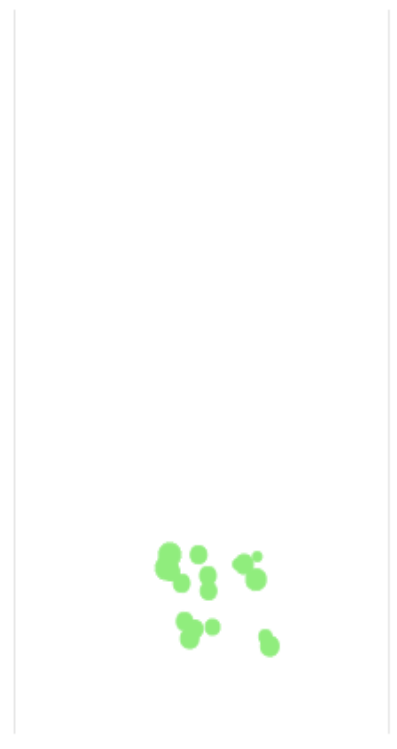

Cluster 3

Gambar 13. Clustering Berdasarkan Volume Usaha

Gambar 13 adalah hasil dari pengelompokan K-means berdasarkan Volume Usaha. Diketahui bahwa hasil pengelompokan data menunjukkan 27 data yang dikelompokkan menjadi 3 kelompok. Klaster pertama adalah 2 Volume Usaha, klaster kedua adalah 8 Volume Usaha dan klaster ketiga adalah 17 Volume Usaha. 


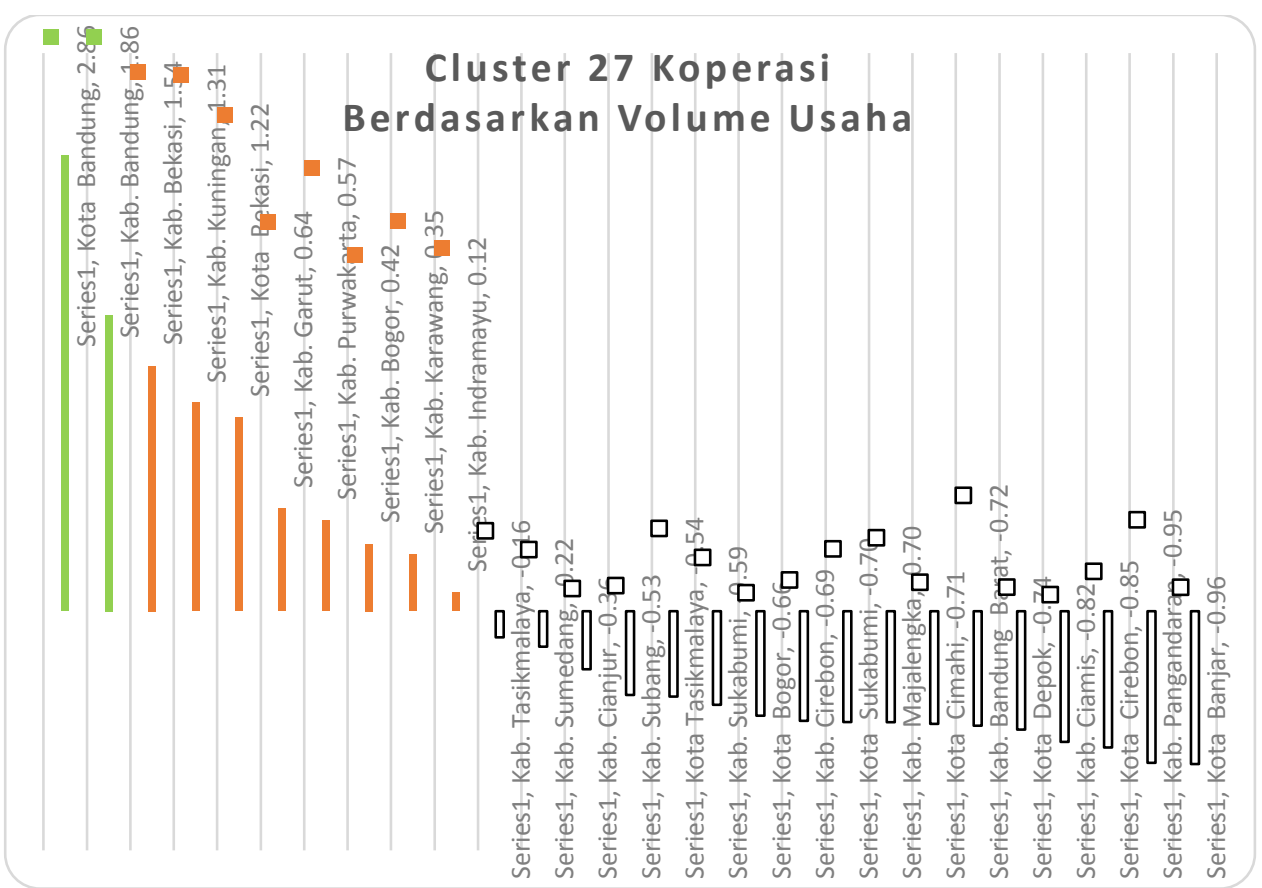

Gambar 14. Clustering Berdasarkan Volume Usaha

Pada Gambar 14 di atas, kita bisa mengetahui nilai Volume Usaha dari setiap koperasi di Jawa Barat. Pada klaster pertama 2 koperasi dengan nilai Volume Usaha 2,699,548,458,687 3,643,455,641,025, klaster kedua dengan 8 koperasi dengan nilai Volume Usaha 1,057,343,264,424 2,397,635,772,946 dan pada kluster ketiga memiliki 17 koperasi dengan Volume Usaha 39,727,849,907 $790,308,648,868$.

\section{KESIMPULAN}

\subsection{Simpulan}

Teknik clustering dengan algoritma K-Means dapat membantu pengelompokkan data pada koperasi di Jawa Barat. Dari 27 koperasi yang diolah datanya, ditentukan 3 titik centroid secara acak dalam 3 klaster pada setiap jenisnya. Sehingga diperoleh nilai berdasarkan Modal Sendiri, Modal Luar dan Volume Usaha. Pada koperasi dengan nilai Modal Sendiri dalam satuan rupiah terdapat klaster pertama 2 koperasi dengan nilai Modal Sendiri 1,238,974,978,653 - 1,768,571,230,077, klaster kedua dengan 5 koperasi dengan nilai Modal Sendiri 701,956,085,063 - 968,512,389,546 dan pada kluster ketiga memiliki 20 koperasi dengan Modal Sendiri 23,491,872,109 - 482,788,640,849. Pada koperasi dengan nilai Modal Luar dalam satuan rupiah terdapat klaster pertama 1 koperasi dengan nilai Modal Luar 2,199,994,077,269, klaster kedua dengan 9 koperasi dengan nilai Modal Luar 488,788,003,415 974,861,971,794 dan pada kluster ketiga memiliki 17 koperasi dengan Modal Luar 8,477,927,928 $456,305,866,411$. Pada koperasi dengan nilai Volume Usaha dalam satuan rupiah terdapat klaster pertama 2 koperasi dengan nilai Volume Usaha 2,699,548,458,687 - 3,643,455,641,025, klaster kedua dengan 8 koperasi dengan nilai Volume Usaha 1,057,343,264,424 - 2,397,635,772,946 dan pada kluster ketiga memiliki 17 koperasi dengan Volume Usaha 39,727,849,907 - 790,308,648,868. Dari hasil tersebut dapat terlihat koperasi mana saja yang harus tetap dipertahankan dan koperasi mana saja yang harus ditingkatkan sehingga dapat membantu meningkatkan perekonomian nasional.

\subsection{Saran}

Berdasarkan hasil penelitian serta pembahasan klaster pada koperasi di Jawa Barat dalam satuan rupiah. Maka untuk pengembangan selanjutnya selain klaster dengan nilai Modal Sendiri, Modal Luar dan Volume Usaha, penelitian ini dapat dikembangkan dengan atribut yang lain. Penelitian ini juga dapat 
dilanjutkan dengan mencoba menggunakan metode klaster lainnya seper Hirarki dan lainya. Selanjutnya dapat ditambahkan lagi faktor apa saja yang dapat mempengaruhi atribut yang sudah dibahas sebelumnya.

\section{REFERENSI}

[1] Tan, P. N. 2018. Introduction to data mining. Pearson Education India.

[2] Anderberg, M. R.(201). Cluster analysis for applications: probability and mathematical statistics: a series of monographs and textbooks. Academic press, 19(1), pp. 1-10

[3] Ross, A. J., Samushia, L., Howlett, C., Percival, W. J., Burden, A., \& Manera, M. 2015. The clustering of the SDSS DR7 main Galaxy sample-I. A 4 per cent distance measure at $z=0.15$. Monthly Notices of the Royal Astronomical Society, 449(1), pp.835-847.

[4] Huang, A. 2008. Similarity measures for text document clustering. In Proceedings of the sixth new zealand computer science research student conference (NZCSRSC2008), Christchurch, New Zealand, 4, pp. 9-56.

[5] Jain, A. K. 2010. Data clustering: 50 years beyond K-means. Pattern recognition letters, 31(8), pp.651-666.

[6] Antonopoulos, P., Nikolaidis, N., \& Pitas, I. 2007. Hierarchical face clustering using sift image features. In 2007 IEEE Symposium on Computational Intelligence in Image and Signal Processing (pp. 325-329). IEEE.

[7] Gil-García, R., \& Pons-Porrata, A. 2010. Dynamic hierarchical algorithms for document clustering. Pattern Recognition Letters, 31(6), pp. 469-477.

[8] Nanda, S. J., \& Panda, G. 2014. A survey on nature inspired metaheuristic algorithms for partitional clustering. Swarm and Evolutionary computation, 16, pp.1-18.

[9] Zhu, A., Wang, G., \& Dong, Y. 2015. Detecting natural scenes text via auto image partition, twostage grouping and two-layer classification. Pattern Recognition Letters, 67, pp.153-162.

[10] Ghosh, S., \& Dubey, S. K. 2013. Comparative analysis of k-means and fuzzy c-means algorithms. International Journal of Advanced Computer Science and Applications, 4(4), pp. 3 10

[11] Windarto, A. P. 2017. Penerapan Datamining Pada Ekspor Buah-Buahan Menurut Negara Tujuan Menggunakan K-Means Clustering Method. Techno. Com, 16(4), pp.348-357. 